Kosjenka Laszlo Klemar

Technical Museum Nikola Tesla

Zagreb

kosjenka.laszlo.klemar@tmnt.hr

Željka Miklošević

Faculty of Humanities and Social Sciences in Zagreb

Zagreb

zmiklosevic@ffzg.hr
DOI: $10.32458 /$ ei.25.10

UDK 069.12(497.5)

Professional paper

Received: $22^{\text {th }}$ May 2020

Accepted: $25^{\text {th }}$ May 2020

\title{
Educational Museum Action - Characteristics and Possibilities of Development
}

On the occasion of observing International Museum Day, Croatian museums carry out the Educational Museum Action (EMA) by conducting educational activities - most often workshops, guided tours and didactic exhibitions - on a specific topic set by a museum-leader. Ethnographic museums in Croatia have participated in the Action from the very beginning; in 2000 and 2010, Ethnographic Museum in Zagreb was the leader of the Educational Museum Action. This paper presents a research of EMA features as an educational museum action conducted by analysis of printed booklets as the Action program publications and by responses of museum experts who took part in the organization and implementation of the Action, obtained as a result of a survey. The research points out the discrepancy between the name and features of the organized activity, upon which a state and potentials of the Action development, as well as the museum's educational activities have been questioned. Curators of ethnographic collections and museum educators in Croatian ethnographic museums, having participated in the research, gave their contribution to determination of issues related to museum educational programs and to determination of their development potentials.

Key words: educational museum action, museum education, Croatia 


\section{INTRODUCTION}

The importance of museums as places of obtaining interesting and diverse information as well as places of learning is frequently emphasized. Education is also emphasized by still valid definition of museums adopted by the International Council of Museums at the $22^{\text {nd }}$ General Assembly in Vienna in 2007 (ICOM 2007), and according to the current Museum Act (Official Gazette 61/18, 98/19) it is one of basic museum activities. Although nowadays only few people would not include educational activities into museum ones, the struggle for recognizing the importance of museum education has been going on for many years, from the 1960s onwards, primarily in international circles, and to some extent in our country too (Bauer 1975, Brezinščak and Jelavić 1996, Jelavić 2011, Majanović 1994, Škarić 2002, 2007, 2010). Despite the large number of papers published about museum educational activities, in our country, primarily in the Proceedings of Museum Educators (Brezinščak 2019), very little has been written about the museum education, its goals and purposes. Even less has been written about a museum education terminology. Therefore, in the absence of generally accepted definitions, the same terms have often been used to denote different contents. The term educational action is such term, and we come across it in the title of the longestrunning museum-pedagogical event of Croatian museums - the Educational Museum Action (EMA).

The aim of this paper is to examine the meaning of this museum event, does it have features of the educational action, what are attitudes and opinions of the museological profession (organizers and implementers) and to discuss, based on results, the state and potentials of its development as well as the profession of museum educator on the whole. In order to obtain a broader and deeper insight into features of the Action, quantitative and qualitative researches aimed at museum educator and other museologists involved in its organization were conducted.

The paper begins with an attempt to define the term educational action, followed by a brief history of the Educational Museum Action (EMA), with special reference to involvement in programs of ethnographic museums, a research methodology, research results, results interpretation and conclusion.

\section{TOWARD TERM DEFINITION}

The word "action" originates from the Latin Actio $\simeq$ agere: to act. The word "action" in the Croatian language has several meanings, the first being "doing, action, undertaking", and the third being "organized social or political activity" (the Croatian language portal). ${ }^{1}$ In English, the word "action" is defined as a process or activity, especially when it comes to a problem (Cambridge Dictionary 2018). According to the stated meanings, the educational action can be interpreted as an organized doing, action, undertaking or process that seeks to achieve a certain goal or solve a certain problem through education. Educational action is a phrase providing the meaning of an activity

1 The second meaning referrs to a specific bank context (Bank., see stocks) and therefore is irrelevant for discussion. 
different from the usual educational practice at schools or museums and the specific educational activity or undertaking.

In a public discourse, educational actions are most often met in the context of the fight against cancer, of ecology and similar topics important to individual groups of people and society on the whole. In museological literature, the term educational action is rarely used. It is used primarily in Latin American countries (Spanish: acción educative), but it is not clearly defined and apparently there is no consensus among museum experts and theorists what it exactly means. From the 1960s to the present day in the context of museums the word "action" has also been mentioned in the phrase cultural action, first in France (action culturelle) and later it spread to other countries. The expansion of the term can also be linked to the work of the ICOM Committee for education in museums, based in France (Committee for Education and Cultural Action - CECA), in which museologists from all over the world, including Croatia, take part. In Croatia, the phrase is present in the title of a HMD section that coordinates EMA (the Section for Museum Education and Cultural Action). Likewise, cultural action is also a phrase that is not defined unambiguously, as is clearly evidenced in the publication ICOM Education 28, dedicated to this very problem (Wintzerith 2018a). Published texts show that both, the educational action and cultural action as well as the museum education are in museums generally understood in different ways, and that they are subjects to different interpretations with regard to specific circumstances in certain socio-cultural contexts. Moreover, the introduction to this publication raises the question of differences between the educational action and the cultural action, if any (Wintzerith 2018b). Anne-Marie Émond and João Pedro Pais Mendonça in their historical review of the museum education and the cultural action in the English part of Canada also consider the contemporary museum practice and clearly distinguish the museum education and the cultural action. According to them, since the end of the $20^{\text {th }}$ century the museum education has included activities such as "guided tours, workshops, programs for schools outside a museum and use of all technological tools", while the museum cultural action have included "development of specific programs, designed for specific needs and in collaboration with a target audience from various communities" (Émond and Pais Mendonç 2018: 102). On the other hand, in the context of Latin America, the museum educational action put emphasis on learning about heritage and includes a series of activities characterized by an implementation strategy worked out in details, defined target groups and a clearly defined pedagogical goal (Aidar and Conrado Martins 2018).

Unlike rather vague definitions of the educational action in the museological literature and the obvious overlaps between understanding the meaning of the museum education, the educational action and the cultural action, Martyn Hammersley, the British sociologist, offers much clearer interpretation of the term; he more precisely distinguishes between the Action with an educational intention and the Action with an intention of informing. According to him, the educational action must: 1 . have a defined specific target audience; 2 . be designed with the intention to achieve a certain change in the perception of a target audience it is directed to, in their attitudes or behavior, in order to meet their needs; 3 . be clearly directed to achieving educational goals - here is important that the education intended to be carried out is really happening; 4. be aware 
that information communication cannot be the primary activity, it can be only one in a series of activities carried out in the process of education (Hammersley 2003: 16). Hammersley opposes these qualities to the informative action, or act of informing, that involves: 1. providing knowledge believed to be of interest to people, 2. care about validity and relevance of the knowledge provided, 3. information communication as the only act, and 4. a rather undefined audience. Following features of the educational action, different from the informative one, and bearing in mind the museological attitudes, we approach, if not to a clear definition, then to the proposed features of an organized event that could be named the museum educational action. The museum educational action would, therefore, be an organized doing, action, undertaking or a process aimed to achieve a specific (educational) goal carried out at museum/s or organized by museum/s. It necessarily differentiates from the regular educational activities. The activities of museums / museum staff under aegis of the Action must have clearly defined target group or groups, defined purposes and types, defined educational goals and must be directed to achieving them.

\section{FROM GAME TO ACTION - BRIEF REVIEW OF EDUCATIONAL MUSEUM ACTION'S DEVELOPMENT}

The Educational Museum Action has been carried out in Croatia for more than two decades and its basic concept has not changed significantly from the very beginning. On the occasion of observing International Museum Day, EMA means pedagogic programs on a specific topic set by the museum-leader. By purchasing a printed booklet with brief information on the Action, topic and programs users get free admission to all included museums and free participation in temporary programs. Croatian ethnographic museums have been participating in the Action from the very beginning and have, in frames of the Action, performed dozens of educational programs.

The first organized educational museum activity unpretentiously titled the Museum Prize Game, was held in 1996 under the title "What Delighted Balthazar in the Museum?" It was initiated by a board of curators - educator from Zagreb museums, organized by the Museum Documentation Center, and led by Želimir Laszlo in collaboration with Tončika Cukrov (Laszlo 1997, Leiner and Brezinščak 2016). The incentive for its launching was the specific situation caused by the Croatian War of Independence. Namely, from 1991 until 1996, due to the danger of war destruction, museum holdings were stored in depots and inaccessible to public. Several generations of children finished lower and enrolled higher grades of primary schools without having the opportunity to visit any museum nor to discover the significance and importance of museum collections, not to mention developing the habit of visiting museums (Laszlo 1997). The action goals were clearly set: 1 . children learn to notice multiplicity and diversity of museums; 2 . children become aware of a large number and types of exhibits; 3. each child takes a closer look at least at one object and learns to read museum labels. To attract children and encourage them to participate, the authors of the concept chose professor Balthazar, a famous character of the famous Croatian homonymous animated series of the 
Zagreb School of Cartoons, as the main character (a kind of a mascot). The game was accompanied by a booklet in which children-participants collected stamps of museums they visited and noted information about museum objects they discovered in museums as a part of the game. Fourteen museums from Zagreb and Zagreb County joined the game, including Ethnographic Museum in Zagreb. It lasted a month, and the closing ceremony was held on International Museum Day, May 18, 1996. The game was not thematically defined, but its content was partly related to the topic of International Museum Day; this year it was collecting (Collecting Today for Tomorrow), so children were collecting museum stamps. It was aimed at individual visitors, while organized (school) visits were deliberately avoided in order not to "force" children to participate. Results were very good - more than 3000 booklets were sold, more than 800 primary school pupils fulfilled all the tasks in the booklet, and more than 2000 children took part in the closing ceremony held at Technical Museum in Zagreb (today Nikola Tesla Technical Museum) (Laszlo 1997).

Although initially conceived as the one-time doing clearly characterized by action with a specific goal and encouraged by the situation of post-war "recovery", due to the great success and interest of museums from other cities to take part, the museum prize game was continued in the following years in the form of one-month events; with time it has become a kind of tradition. In 1997, the Action was organized by museums and the first among them was Archaeological Museum in Zagreb. After the Section for Museum Education was established at the Croatian Museum Association in 1999, it took over from the Museum Documentation Center the function of the competent body (leader) that confirms/selects museums-organizers. From 1997 to 2020, nineteen museums took a role of organizers, including Ethnographic Museum in Zagreb, performing this function twice - in 2000 (topic "2000") and in 2010 (topic "Wheel"). Since 1997, every museum Action has a central topic designed by the museum-organizer.

According to the museum pedagogy development in Croatia (that after stagnation in the first half of the 1990s experienced take-off at the time of launching the prize game "What Delighted Balthazar in the museum?"), the content of the action developed too, and over the year's number of cities and museums involved increased (Leiner and Brezinščak 2016).

The best insight into the development of educational museum actions is provided by Program booklets printed with every Action. Besides information about the museumorganizer and the central theme, they contain lists of included museums as well as descriptions of the program. Thanks to this, the gradual spreading of the Action from Zagreb and Zagreb County can be followed, first to the neighboring Krapina-Zagorje County (1999) and then during the 2000s, to the rest of Croatia. At the $11^{\text {th }}$ Museum Educational Game with the theme "Sound... Tone... Voice" held in 2006 (organizer: Croatian History Museum, Zagreb) all regions of Croatia, a total of 42 institutions from 20 cities took part (besides museums in the early 2000s the related institutions, primarily galleries and archives, started to join). Besides Ethnographic Museum in Zagreb, other ethnographic museums throughout Croatia became also involved into the Action. 
In 2006 the territorial expansion was followed by the target audience expansion, so high school students and "all interested people" joint the audience of primary school children (Cukrov 2006, Smetko 2006). The expansion of the target audience onto young people can be connected with that year ICOM topic of International Museum Day "Museums and young visitors". Ethnographic museums also reacted to the Action with workshop programs about traditional instruments (Zagreb about tamburizza (a longneck string instrument), Istria about sopele, Split about fiddle, mandolin and dowels); only the program of Ethnographic Museum in Zagreb included a visit to exhibitions with a film; its approach to the topic was problematical, encouraging controversy and discussion (the program title: Tamburizza - a symbol of Croatian national identity? the author of the exhibition: Zvjezdana Antoš; the author of the educational program: Željka Jelavić) thanks to this background the program was more suitable for high school students's participation. It is also interesting that in 2008 the title of the Action was changed from "Museum Educational Prize Game" to "Museum Educational Action and Prize Game", but in 2010 and 2011 the old title ("Museum Educational Game") was returned. Since 2012, only the title "Museum Educational Action" has been used, and since 2016, it was used together with the abbreviation EMA. Title changes did not result with change of a game/action concept. It has not changed at all; during the month of the game/action, participants visit museums and collect stamps in a booklet; the game ends with a big ceremony on International Museum Day (May 18) where prizes are awarded (the last page of the booklet with collected stamps is sent to the museum-organizer address for the prize to be drawn).

In order to emphasize the connection with International Museum Day organized by the International Council of Museums (ICOM) the title always has the addition "on the occasion of International Museum Day". This connection primarily refers to the date of taking part, i.e. the grand "finale" on International Museum Day, while topics are seldom related to the topic of ICOM.

\section{RESEARCH METHODOLOGY}

To determine characteristics of the Action in Croatian museums, we relied on the definition of the educational action based on afore stated premises of Martyn Hammersley (2003), on features of the museum educational action at Latin American museums (Aidar and Conrado Martins 2018), and on cultural actions of English-speaking Canadian museums (Emond and Mendonça 2018). The research objective was to find to what extent the Croatian museum action with its features fall into the following categories: 1. defined specific target audience, 2. defined type and purpose of activities, 3. defined educational goals and focus on achieving them.

Data were collected by a thorough analysis of the booklets as the main publications of all EMAs that already took place and by an online survey with open-ended and closeended questions about the Action participants' activities. The target group of respondents were museum educators and curators who most often organize or conduct the Educational Museum Actions, especially if a museum has not employed a museum educator, as shown in the previous researches conducted at Croatian museums (Škarić 2010). 
Addresses were obtained from the Museum Documentation Center (Croatian Museums and Collections Online) database and from the Action Program Booklets. Because it was impossible to know which curators participated in the Action, the selection of addresses for a survey sending was rather random; nevertheless, by e-mails it was requested to forward the survey to those who took part in any Action but possibly did not get the survey. On $30^{\text {th }}$ September 2018, the anonymous survey was sent to 209 e-mail addresses of curators (146) with basic and senior titles and museum educator (63); data were analyzed including the survey form sent on $31^{\text {st }}$ October, 2018. Obtained data were processed by a descriptive statistics method (numerically processable closeended questions) and by qualitative and quantitative thematic analysis of the content (open-ended questions with a text as a result). 141 museologist opened and started to fill in the survey and 101 of them continued with the task. By the end of the survey, 93 participants answered the question: "Have you personally participated in organization and/or implementation of the program?"; 70 participants answered all questions, making $75.2 \%$ of the total. A total of 24 questions were asked, some of which offered, according to respondents wishes, additional space for comments. The first set of questions referred to work positions and a type of museum in which the respondents work and to the participation (museum and in a person) in EMA. The second set of questions was related to types of visitors and programs during the Action and its contribution to users. The third set of questions measured the degree of agreement with statements about the Action organization, the program booklet, the Action topics, changes caused by the Action and a form of implementation in the future. Having in mind the topic of this paper, the presentation of research results obtained upon a survey will be presented only in relation to the second and partly the third group of questions, as these groups are relevant to the research question.

\section{RESULTS OF PROGRAM BOOKLETS ANALYSIS}

Analysis of booklets is presented in accordance with default categories.

\section{Defined specific target audience}

Children of primary school age were a clearly defined target group of the first Educational Museum Action / prize game "What Delighted Balthazar in the Museum?" (1996). Individual visitors were also overtly targeted, while organized (school) visits were deliberately avoided. In the following years that primary school children were still the target group. Only in 2006 high school students as well as "all interested" were together with primary school children included into the target group, as stated in the text about already carried out Action (Cukrov 2006, Smetko 2006), although in booklets with individual programs (descriptions of activities) of involved museums it was not specified to what target groups the program was intended for. This practice was continued in the following years, and individual museums programs have mentioned the target group only exceptionally. The program booklet has been (especially since 2016 when the girl Ema was introduced as the central character/mascot) designed and 
adapted to children of lower primary school age, but introductory texts (even after 2016) besides children have mentioned young people even "all ages" as the target audience. In relation to the initial idea a change is represented by the increasing focus on group, school visits (most likely under the pressure of achieving a larger number of users, author's remarque), what was consciously tried to be avoided in the first Action in 1996.

\section{Types and purposes of activities}

Types of activities carried out as part of the museum educational action can be read out from the description of activities of the museums involved. The first action, directed to encouraging individual research of a museum did not, for understandable reasons, include organized activities aimed at any group of users, except as part of the award ceremony. In the following years, with focus shifted to group visits, the number of activities increased including workshops, theme-based guided tours, lectures and didactic exhibitions, i.e. more or less all types of activities related to museum-educational practice. Nevertheless, especially since 2006 the dominance of creative workshops has been noticeable, prevailing at that time as the dominant type of museum-pedagogical programs in Croatian museums. Anyway, at the program level no shift from the usual museum-pedagogical practice could be determined. Program descriptions of individual museums do not state the purpose of the activity.

\section{Defined educational goals and focusing on their implementation}

The first educational action held in 1996 had clearly defined educational goals: 1. children learn to notice multiplicity and diversity of museums; 2 . children become aware of a large number and types of exhibits; 3. every child takes a closer look at least at one object and learns to use a museum label. To achieve these goals, a workbook with tasks was printed for children to complete them. In the following years, goals were not clearly set, and from the introductory texts in the program booklets, you can read out their focus on increasing the number of visitors, promoting the museums, preserving the heritage and the like.

\section{SURVEY RESULTS}

A total of 24 questions were asked, some of which with space for comments, according to respondents wishes. The first set of questions referred to jobs and types of museums in which respondents worked and participated in EMA (museums as well as persons). The second set of questions was related to types of visitors and programs during the Action and to its contribution to users. The third set of questions measured the degree of agreement with the statements about the Action organization, the program booklet, the Action topics, changes the Action causes and a form of the Action implementation in the future. Beside basic information about participants and duration of their participation in the Action, here are presented answers to questions related to the research question, 
i.e. questions concerning target groups, types and purposes of activities, educational goals and orientation to the goals achieving. Out of 93 people personally participating in EMA, 16 are directors, 39 are curators, and 34 are museum educators (at all levels, from trainees to advisors) and 6 people work at other jobs (PR, professional associates, and documentalist). They come from different backgrounds according to the following percentages: settlements with less than 10 thousand inhabitants $-22.1 \%$, between 10 and 50 thousand inhabitants $-27.3 \%$ and more than 50 thousand inhabitants $-50.5 \%$. By duration of active participation in actions implementation, 27 museologists participated in the period of 1 - 5 years, 20 of them in the period of 6 - 10 years and 19 employees in the period of 11 and more years. The longest duration has been 23 years ( 1 person).

Answers to the first two questions refer to target groups, group and individual visits (Fig. 1 and 2).

Figure 1. For which groups of visitors and how often activities within the Action intended for organized groups are organized/carried out?

\begin{tabular}{|c|c|c|c|c|c|c|}
\hline & Never & $\begin{array}{l}\text { Extremely } \\
\text { seldom }\end{array}$ & Seldom & Povremeno & Periodically & Often \\
\hline $\begin{array}{l}\text { Groups of preschool } \\
\text { children }\end{array}$ & $2.70 \%$ & $12.20 \%$ & $8.10 \%$ & $25.70 \%$ & $29.70 \%$ & $21.60 \%$ \\
\hline $\begin{array}{l}\text { Groups of children } \\
\text { (elementary grades) }\end{array}$ & $1.40 \%$ & $1.40 \%$ & $2.70 \%$ & $12.20 \%$ & $25.70 \%$ & $56.80 \%$ \\
\hline $\begin{array}{l}\text { Groups of children } \\
\text { (intermediate grades) }\end{array}$ & $2.70 \%$ & $2.70 \%$ & $5.40 \%$ & $16.20 \%$ & $36.50 \%$ & $36.50 \%$ \\
\hline $\begin{array}{l}\text { Groups of young } \\
\text { people (18-25) }\end{array}$ & $11.40 \%$ & $15.70 \%$ & $20.00 \%$ & $21.40 \%$ & $24.30 \%$ & $7.10 \%$ \\
\hline Groups of adults $(25-65)$ & $19.40 \%$ & $20.80 \%$ & $15.30 \%$ & $23.60 \%$ & $16.70 \%$ & $4.20 \%$ \\
\hline $\begin{array}{l}\text { Groups of children } \\
\text { (high school) }\end{array}$ & 4. $10 \%$ & $11.00 \%$ & $8.20 \%$ & $27.40 \%$ & $30.10 \%$ & $19.20 \%$ \\
\hline $\begin{array}{l}\text { Groups of adults over } \\
65\end{array}$ & $27.80 \%$ & $22.20 \%$ & $19.40 \%$ & $23.60 \%$ & $4.20 \%$ & $2.80 \%$ \\
\hline $\begin{array}{l}\text { Groups of adults and } \\
\text { children/ young people } \\
\text { (families) }\end{array}$ & $20.50 \%$ & $23.30 \%$ & $23.30 \%$ & $23.30 \%$ & $8.20 \%$ & $1.40 \%$ \\
\hline $\begin{array}{l}\text { Groups of young } \\
\text { people and adults with } \\
\text { disabilities }(18+)\end{array}$ & $18.10 \%$ & $36.10 \%$ & $16.70 \%$ & $26.40 \%$ & $1.40 \%$ & $1.40 \%$ \\
\hline $\begin{array}{l}\text { Groups of children with } \\
\text { disabilities }\end{array}$ & $27.80 \%$ & $25.00 \%$ & $16.70 \%$ & $23.60 \%$ & $4.20 \%$ & $2.80 \%$ \\
\hline $\begin{array}{l}\text { Groups of ethnic } \\
\text { minorities members }\end{array}$ & $48.60 \%$ & $22.90 \%$ & $11.40 \%$ & $11.40 \%$ & $1.40 \%$ & $4.30 \%$ \\
\hline
\end{tabular}


Figure 2. For what types of visitors and how often activities within the Action intended for individual participation or visit are organized/carried out?

\begin{tabular}{|c|c|c|c|c|c|c|}
\hline & Never & $\begin{array}{l}\text { Extremely } \\
\text { seldom }\end{array}$ & Seldom & Periodically & Often & $\begin{array}{l}\text { Extremely } \\
\text { often }\end{array}$ \\
\hline Preschool children & $11.00 \%$ & $17.80 \%$ & $6.80 \%$ & $19.20 \%$ & $26.00 \%$ & $19.20 \%$ \\
\hline $\begin{array}{l}\text { Children at the age of } \\
\text { elementary grades }\end{array}$ & $6.80 \%$ & $9.50 \%$ & $5.40 \%$ & $21.60 \%$ & $24.30 \%$ & $32.40 \%$ \\
\hline $\begin{array}{l}\text { Children at the age of } \\
\text { intermediate grades }\end{array}$ & $8.10 \%$ & $9.50 \%$ & $6.80 \%$ & $28.40 \%$ & $23.00 \%$ & $24.30 \%$ \\
\hline $\begin{array}{l}\text { Children at the age of } \\
\text { high school }\end{array}$ & $11.30 \%$ & $11.30 \%$ & $16.90 \%$ & $38.00 \%$ & $9.90 \%$ & $12.70 \%$ \\
\hline $\begin{array}{l}\text { Young people between } \\
18 \text { and } 25 \text { (students and } \\
\text { high school graduates) }\end{array}$ & $18.10 \%$ & $15.30 \%$ & $26.40 \%$ & $22.20 \%$ & $13.90 \%$ & $4.20 \%$ \\
\hline $\begin{array}{l}\text { Adults between } 25-65 \\
\text { years }\end{array}$ & $21.40 \%$ & $18.60 \%$ & $18.60 \%$ & $28.60 \%$ & $8.60 \%$ & $4.30 \%$ \\
\hline Adults over 65 years & $20.50 \%$ & $30.10 \%$ & $20.50 \%$ & $19.20 \%$ & $5.50 \%$ & $4.10 \%$ \\
\hline $\begin{array}{l}\text { Adults with children/ } \\
\text { young people (families) }\end{array}$ & $16.70 \%$ & $15.30 \%$ & $20.80 \%$ & $30.60 \%$ & $8.30 \%$ & $8.30 \%$ \\
\hline $\begin{array}{l}\text { Young people and } \\
\text { adults with disabilities }\end{array}$ & $28.60 \%$ & $31.40 \%$ & $15.70 \%$ & $18.60 \%$ & $2.90 \%$ & $2.90 \%$ \\
\hline $\begin{array}{l}\text { Children with } \\
\text { disabilities }\end{array}$ & $25.40 \%$ & $33.80 \%$ & $18.30 \%$ & $15.50 \%$ & $4.20 \%$ & $2.80 \%$ \\
\hline $\begin{array}{l}\text { Members of ethnic } \\
\text { minorities }\end{array}$ & $47.10 \%$ & $25.70 \%$ & $12.90 \%$ & $12.90 \%$ & $\%$ & $1.40 \%$ \\
\hline
\end{tabular}

Answers show the highest frequency of program implementation for groups of children in lower grades of primary schools, which is in line with the graphic communication in the program booklet. The next level of frequency are children of upper grades of primary school, preschoolers and high school students. As other groups of visitors, respondents listed groups of foreign visitors, professional associations, and college students.

As the basic communication medium (the booklet) does not indicate to whom the Action is intended, the research results indicate that individual museums address a wider circle of users.

The most frequent answers to questions about types of activities and a frequency of their implementation (Fig. 3) are workshops and theme-based guided tours, but to a lesser extent, other forms of activities also appear.

Answers point out that there is not a single museum never having organized workshops on the Action occasion. As other activities (not being offered) educational publications, plays, concerts, theme-based guided tours at temporary exhibitions and related to a 
selected work, field research together with users and visits to artists, were listed. The above mentioned indicates that museums organize activities according to their own capabilities and ideas. Some types of activities, such as organized courses and public forums, additionally suggest expanding the users' base from school-age children to adults. A large number of workshops and guided tours at an exhibition also shows that activities carried out as a part of the Action are identical to activities carried out as a regular museum-pedagogical practice.

Answers to the question about the program and activity evaluation (Fig. 4) show that majority of museums do not practice evaluation.

Respondents who conducted the evaluation were able to choose one or more offered answers about the exact evaluated topic: Users satisfaction (18), Users' experience of the program/activity (17), Interest in the content of the museum (12), Interest in the topic of the program/activity (9), Acquired knowledge (7), Learning modes (e.g. cognitive, social ... visual, motor ...) (1). Answers show that the evaluation is based on the surveying users' experience and satisfaction. Only 8 people chose the evaluation option referring to the acquired knowledge or way of learning.

Concerning the question about the success of actions, approximately one third of respondents answered that it was the success that was determined in their museums; the empty space was intended for the list of ways it was done and it was filled with following data: number of visitors and visits, surveys (evaluation) and oral comments of participants, number of programs and media coverage.

Figure 3. What types of activities referring the Action topic and how often are they organized/carried out at your museum?

\begin{tabular}{|c|c|c|c|c|c|c|}
\hline & Never & $\begin{array}{l}\text { Extremely } \\
\text { seldom }\end{array}$ & Seldom & Periodically & Often & $\begin{array}{c}\text { Extremely } \\
\text { often }\end{array}$ \\
\hline Workshops & $\%$ & $2.60 \%$ & $1.30 \%$ & $13.20 \%$ & $19.70 \%$ & $63.20 \%$ \\
\hline Lectures & $8.30 \%$ & $13.90 \%$ & $8.30 \%$ & $33.30 \%$ & $25.00 \%$ & $11.10 \%$ \\
\hline Didactic exhibitions & $5.60 \%$ & $12.70 \%$ & $7.00 \%$ & $28.20 \%$ & $25.40 \%$ & $21.10 \%$ \\
\hline Playgroups & $14.90 \%$ & $12.20 \%$ & $8.10 \%$ & $18.90 \%$ & $23.00 \%$ & $23.00 \%$ \\
\hline Debates & $52.20 \%$ & $24.60 \%$ & $10.10 \%$ & $13.00 \%$ & $\%$ & $\%$ \\
\hline Round tables & $52.20 \%$ & $24.60 \%$ & $11.60 \%$ & $10.10 \%$ & $\%$ & $1.40 \%$ \\
\hline $\begin{array}{l}\text { Theme-based guided } \\
\text { tours of the permanent } \\
\text { exhibition }\end{array}$ & $2.80 \%$ & $5.60 \%$ & $4.20 \%$ & $5.60 \%$ & $35.20 \%$ & $46.50 \%$ \\
\hline Public forums & $62.30 \%$ & $23.20 \%$ & $7.20 \%$ & $4.30 \%$ & $2.90 \%$ & ०\% \\
\hline Instruction courses & $63.20 \%$ & $19.10 \%$ & $10.30 \%$ & $7.40 \%$ & ०\% & ०\% \\
\hline
\end{tabular}


Figure 4. Has your museum ever conducted a program/activities evaluation as a part of the Action by surveying users/visitors?

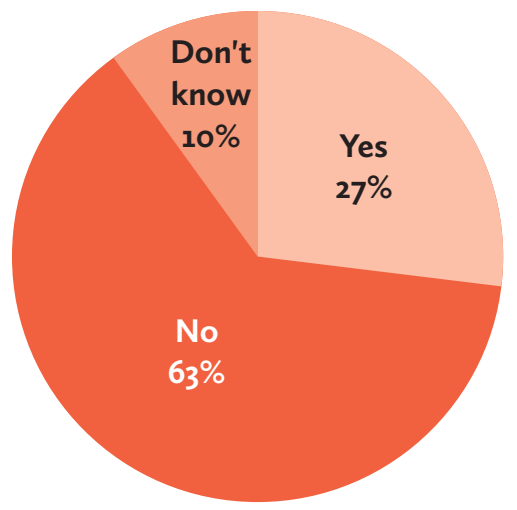

Figure 5. Does your museum practice evaluation of success of its EMA activities?

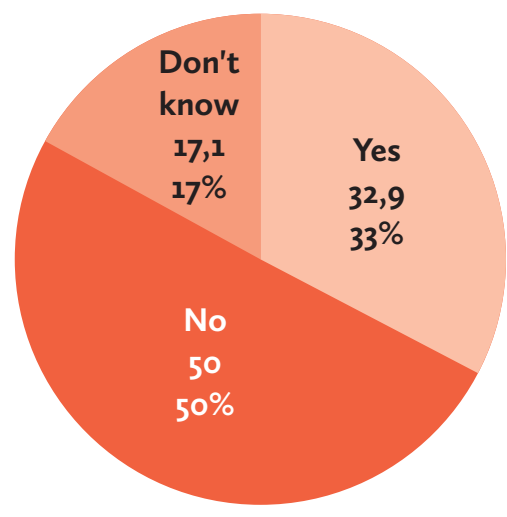

Figure 6. To which extent do you agree with claims offered? (1 - not at all, 5 - completely)

\begin{tabular}{|c|c|c|c|c|c|}
\hline & 1 & 2 & 3 & 4 & 5 \\
\hline $\begin{array}{l}\text { The Museum Education Section organizes the } \\
\text { Educational Museum Action well }\end{array}$ & $1.60 \%$ & $10.90 \%$ & $18.80 \%$ & $35.90 \%$ & $32.80 \%$ \\
\hline $\begin{array}{l}\text { The Section/Assoc iation promotes the Action in } \\
\text { media well }\end{array}$ & $6.30 \%$ & $21.90 \%$ & $18.80 \%$ & $32.80 \%$ & $20.30 \%$ \\
\hline $\begin{array}{l}\text { My museum has to get engaged in promotion } \\
\text { independently }\end{array}$ & $\%$ & $1.60 \%$ & $25.00 \%$ & $20.30 \%$ & $53.10 \%$ \\
\hline $\begin{array}{l}\text { It is good museums participate in the Action financ } \\
\text { ially (registration fee, purchase of additional booklets) }\end{array}$ & $14.10 \%$ & $18.80 \%$ & $31.30 \%$ & $17.20 \%$ & $18.80 \%$ \\
\hline $\begin{array}{l}\text { The museum provides me with conditions necessary } \\
\text { for the Action implementation }\end{array}$ & $4.70 \%$ & $12.50 \%$ & $12.50 \%$ & $21.90 \%$ & $48.40 \%$ \\
\hline $\begin{array}{l}\text { Museum colleagues help with program organisation } \\
\text { during Actions }\end{array}$ & $12.50 \%$ & $12.50 \%$ & $21.90 \%$ & $15.60 \%$ & $37.50 \%$ \\
\hline $\begin{array}{l}\text { Museum colleagues help with the program } \\
\text { implementation during Actions }\end{array}$ & $12.50 \%$ & $14.10 \%$ & $25.00 \%$ & $15.60 \%$ & $32.80 \%$ \\
\hline Target groups show great interest in Action programs & $7.80 \%$ & $15.60 \%$ & $35.90 \%$ & $26.60 \%$ & $14.10 \%$ \\
\hline $\begin{array}{l}\text { The Action is necessary because it helps to increase } \\
\text { the number of visitors during the year }\end{array}$ & $4.70 \%$ & $25.00 \%$ & $26.60 \%$ & $14.10 \%$ & $29.70 \%$ \\
\hline $\begin{array}{l}\text { The Action is necessary because museums otherwise } \\
\text { do not offer enough content for children }\end{array}$ & $18.80 \%$ & $28.10 \%$ & $17.20 \%$ & $21.90 \%$ & $14.10 \%$ \\
\hline $\begin{array}{l}\text { Activities planned as a part of the Action in my } \\
\text { museum are readily funded (leastwise by small } \\
\text { amounts) }\end{array}$ & $6.30 \%$ & $9.40 \%$ & $14.10 \%$ & $25.00 \%$ & $45.30 \%$ \\
\hline
\end{tabular}


Table 1. What is contribution of museum EMA activities to visitors, i.e. museum users?

\begin{tabular}{|c|c|}
\hline MUSEUM PERSPECTIVE & USERS PERSPECTIVE \\
\hline $\begin{array}{l}\text { Promotion of museums and museum collections } \\
\text { (10) }\end{array}$ & $\begin{array}{l}\text { Learning and obtaining information about a } \\
\text { specific topic or content ( } 9 \text { ) }\end{array}$ \\
\hline $\begin{array}{l}\text { More visits and visitors ( } 7 \text { ), creating new museum } \\
\text { audience (2), Educating the audience (3) }\end{array}$ & Quality leisure time - education through fun (4) \\
\hline Enriched content ( 7 ) & Stimulating curiosity and interest (1) \\
\hline $\begin{array}{l}\text { Get acquainted with activities and significance of } \\
\text { a museum (7) }\end{array}$ & Development of knowledge, interests, skills (2) \\
\hline Promotion of publications ( 1 ) & Development of critical thinking (1) \\
\hline $\begin{array}{l}\text { Promotion of heritage ( } 2 \text { ) and educational } \\
\text { activities (1) }\end{array}$ & $\begin{array}{l}\text { Development of creative expression and } \\
\text { researches (2) }\end{array}$ \\
\hline \multirow{2}{*}{$\begin{array}{l}\text { Sensibilization of (non) visitors concerning } \\
\text { museums (3) }\end{array}$} & Development of one's own cultural identity (1) \\
\hline & Free/cheaper visit and/or participation (5) \\
\hline
\end{tabular}

Attitudes about three questions concerning perception of the necessity of the Action (Fig. 6) are divided. Interest in the Action varies, as well as its impact on increasing the number of visitors to the museum in general.

Answers to the question about the contribution of the Action to users (Table 1) were processed applying thematic analysis that provided two categories: a museum perspective (left) and users' perspective (right). The museum perspective encompasses outcomes that actually contribute to museums, and users' perspective refers to outcomes that contribute to users. Outcomes are accompanied by a number of the answers.

The mentioned analysis points out that only few outcomes can be put into connection with specific educational goals (development of critical thinking, creative expression, research and development of one's own cultural identity). From the above mentioned, it is evident that for majority of museums (or at least for those who carried out activities), the Action represents primary means for promoting the institution, museum activities and for raising awareness about museums.

Concerning changes resulted the Action caused (Fig. 7) opinions were rather uniformed. Respondents least agree with the statement that the implementation of the Action has led to positive changes in the society (among museum users). The analysis of comments on this issue shows the following attitudes related to positive changes in specific museums and museums in general: greater range of educational museum materials and educational activities, greater visibility and more positive attitude towards museums, expanding users' base (young and adults together with children).

In the last question in the survey, aimed to show the opinion about the (possible) further development of the Action, respondents were asked how the Action should be implemented in the future (Fig. 8). Answers were the following: abolish, implement in 
Figure 7. To which extent do you agree with the following statements? (1 - not at all, 5 - completely)

\begin{tabular}{|c|c|c|c|c|c|c|}
\hline & 1 & 2 & 3 & 4 & 5 & Average \\
\hline $\begin{array}{l}\text { The implementation of the Action/s } \\
\text { has led to positive changes in my } \\
\text { institution }\end{array}$ & $9.40 \%$ & $14.10 \%$ & $25.00 \%$ & $18.80 \%$ & $32.80 \%$ & 3.5 \\
\hline $\begin{array}{l}\text { The implementation of the Actions has } \\
\text { led to positive changes in museums in } \\
\text { general }\end{array}$ & $0.00 \%$ & $14.10 \%$ & $28.10 \%$ & $31.30 \%$ & $26.60 \%$ & 3.7 \\
\hline $\begin{array}{l}\text { The implementation of the Actions } \\
\text { has led to positive changes in a society } \\
\text { (among museum users) }\end{array}$ & $6.30 \%$ & $21.90 \%$ & $29.70 \%$ & $23.40 \%$ & $18.80 \%$ & 3.3 \\
\hline
\end{tabular}

a different form, implement in the same form as before and some other suggestions. The answers were different and with a very small percentage of those who no longer wanted it. Very small advantage was given to the opinion that the Action should be carried out in a different form.

In the category "other suggestions" some changes were proposed including the following specific once: 1 . implement in the same form and supplement with a digital application, 2. do not change the content, but insist on media promotion so the Action would attract as many users as possible, 3. adapt to needs of society based on a feedback from participants.

Comments at the end of the survey in space not related to any question but provided for those who would like to add something mainly relate to searching a new concept or to positive evaluations of the Action. They confirm a fact of different opinions about the possible future form of the Action. Here we quote comments we consider important for a discussion:

"The Action should be completely redefined; the current practice shows slightly modifying of existing activities in order to fit into the Action frame, but it does not increase

Figure 8. Opinions about implementation of the Action in the future

Implemented in the same form as before

Implemented in a different form

Eliminate

Other (enter)

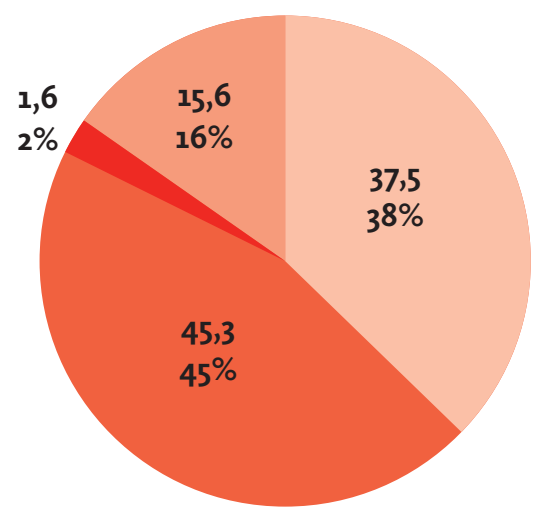


visibility of our content; for users we fight by ourselves; the booklet doesn't really have any function, especially because we get 5 pieces - quantity just for the archive -and I'm not sure it provides users with information they need."

"Unfortunately, the Action is not alive any longer; it is not the important thing necessary for museum institutions."

"The Action is positively evaluated by users. The involved persons follow programs with interest and joy, but the public is generally under informed about the Action, so the response is relatively modest."

"I praise the Action, since 2013 thanks to it a large number of museum workshops and additional programs have been launched in our museum (and outside the Museum Day), which finally resulted in hiring a museum educator and designing a year-round system of workshops and education."

\section{DISCUSSION}

The analysis of the Educational Museum Action (EMA) program booklet raised several key questions. Among them stands out that of the target group of users - group or individual visits, and age group of users. This question is important from the perspective of reasons for the Action initiating, as well as of the practice that should be implemented in the future. Namely, as several times have been pointed out, the first Action, i.e. the educational game in 1996, was intended exclusively for primary school children that independently, as individual visitors (accompanied by an adult) used to visit museums. After more than 20 years, the survey showed that profiles range for participants for whom activities were organized during the Action, has significantly expanded. It is not a problem, but from the point of view of the organized Action that should have a clearly defined target group and a clearly defined goal (in this case at the state level), the diverse data obtained by the survey and analysis of the booklet encourage questioning of the Action meaning as a unique event. Of course, it is also possible to ask the question of sustainability and meaningfulness of the Action, that has neither defined general nor specific goals, making impossible to monitor have they been achieved and to what extent. In other words, the goals less indicate features of educational action and more features of informative action (Hammersley 2003).

Answers about the Action usefulness the most illustratively show that museologists, namely those who organize and/or conduct educational activities, perceive the Action more as a promotional program primarily animating and sensitizing, rather than dealing with achieving specific educational goals. A very similar attitude about necessity to sensibilize and animate visitors was highlighted in the Croatian context of the 1970s and 1980s (Bauer 1975, Majanović 1994), when there was a need. The twenty-first century, with much more developed marketing-oriented thinking and actions, leaves enough space for educational activities to focus on achieving "higher" and even socially relevant goals in terms of pointing out current social problems and contributing to their solution; in modern times it is recognized as one of the primary museum roles (Brown 
and Mairesse 2018, Fleming 2016). Further researches of museum educational action could therefore focus on researches from the aspect of socially engaged museum activities, i.e. it could include aspects of social action too (Hein 2010). On this background, the research offered only one approach to the educational action determination. The research pointed out that the Educational Museum Action currently carried out in Croatia, except the variety of activity types, lacks sufficient elements upon which it could be characterized as a specially organized undertaking with the aim of educating a defined group of users and with a purpose of achieving specifically defined effects. Program publications do not specify the Action implementation at the level of joint action. The Action is just a call for as much involvement as possible, which is a self-serving purpose. At the same time, it is justifiably understood that every type of education is desirable and valuable. The education implementation with not defined specific goal should be a part of the regular museum practice, not merely a reaction to the Action, i.e. the Action should not be an excuse to conduct ceertain educational activities once a year. Unfortunately, or maybe fortunately, it often happens due to lack of financial conditions, but in some cases due to still insufficient awareness of a management and founders about the need to conduct educational activities and (often) to nonexistence of a museum educator work position. In larger museums the educational activity as a part of the regular practice and the Action implementation decision is often in charge of an individual (a museum educator); it depends on him/her and how he/she will understand it: as an upgrade in terms of the Action specific form or as a programs/ activities adaptation, carried out in the regular practice. Answers to the question about the Action further development and some comments point to the fact that some individuals have a very developed awareness about necessity to change the Action in a form of upgrading. Concerning actions as special ventures, it is umbrella organizers, who should rise the awareness about necessities of the Action changes/upgrades and give encouragement and guidance to others.

\section{CONCLUSION}

More than two decades of organized activities as a part of the museum educational game/action, at the beginning only at Zagreb museums and later at majority of Croatian museums, deserves every praise. No doubt the Action is very valuable (and in a global context unique) museum tradition, conceived in specific (unfavorable) post-war circumstances. There is also no doubt that the Action contributed to the affirmation of the museum-pedagogical profession. Consequently, it is not surprising that museologists (primarily museum educator) are interested in maintaining such activities. However, as the profession has strengthened over the years, the Action frame changes, i.e. thinking over and defining new goals arising from modern circumstances as well as responding to modern challenges would be normal to expect.

Except for the expansion of the target group, not accompanied by substantive changes in terms of adapting the concept, activities and even the design of the promotional material, the research showed no progress. Moreover, the results indicate the organized educational action is primarily understood as the action aimed at popularizing 
museums and museum contents and information communicating. The Educational Museum Action (EMA) has no features of the educational action in terms of meeting previously mentioned key criteria - addressing a clearly defined target group, clearly defined activities and purposes, and clearly defined educational goals as well as focus on their implementation. What more, the analysis indicates the game conducted in 1996 has satisfied the above mentioned criteria better than the Educational Museum Action, especially since 2006 until nowadays. The state of affairs can be partly explained by still insufficient number of museum educators in museums, i.e. insufficient capacities that are necessary for introducing changes (and implementation), but the survey answers (especially the small number of comments at the end of the survey) indicate a lack of interest to consider the Action purposes and goals. As the longestrunning organized museum-pedagogical activity in Croatia the Educational Museum Action for sure has the potential to develop into the educational action in the full sense of the word; however, the precondition for this should be a thorough re-examination of the museum-pedagogical profession in Croatia, because it was additionally shaken by abolition of Rules on professional museum titles and other titles in the museum activities and of requirements and procedures of their acquisition, adopted in 2019.

\section{REFERENCES AND SOURCES:}

AKCIJA, Hrvatski jezični portal, http://hjp.znanje.hr/index.php?show=search (visited on $25^{\text {th }}$ February 2020).

ACTION, Cambridge Dictionary, 2018. https://dictionary.cambridge.org/dictionary/english/ action (visited on $25^{\text {th }}$ February 2020).

AIDAR, Gabriela and Luciana CONRADO MARTINS. 2018. "Cultural action in museums: What do professionals and researchers think in the Latin American context?" In: ICOM Education 28 - Cultural Action, Stéphanie Wintzerith ed. Paris: ICOM CECA p. 159-173.

BAUER, Antun. 1975. "Muzejska pedagogija”. Muzeologija 17: 101-111. https://doi. org/10.1137/1017006

BREZINŠČAK, Renata. 2019. Bibliografija radova objavljenih u zbornicima skupova muzejskih pedagoga hrvatske od br. I. do VIIIs. (2002. - 2015.). Zagreb: Hrvatsko muzejsko društvo, http://www.hrmud.hr/sekcija_pedagoga/Zbornici_Skupova_muzejskih_pedagoga_Hrvatske_bibliografija.pdf (visited on $30^{\text {th }}$ March 2020).

BREZINŠČAK, Renata and Željka JELAVIĆ. 1996. "Uloga i status kustosa pedagoga u djelatnosti muzeja”. Anali Galerije Antuna Augustinčića, 16/17: 101-106. http://muzejska-edukacija. com/uloga-i-status-kustosa-pedagoga-u-djelatnosti-muzeja/ (visited on $12^{\text {th }}$ April 2012).

BROWN, Kareb and Francois MAIRESSE. 2018. "The definition of museum through its social role". Curator 61 (4): 1-15. https://doi.org/10.1111/cura.12276

CUKROV, Tončika. 2006. "Međunarodni dan muzeja 2006. “ Informatica Museologica, 37 (1-4): 188-201.

ÉMOND, Anne-Marie and João Pedro PAIS MENDONÇA. 2018. "Cultural action-making in English Canada's museums: a historical overview 1840-2018”. In: ICOM Education 28 Cultural Action, Stéphanie Wintzerith ed. Paris: ICOM CECA p. 89-108. 
FLEMING, David. 2016. "Post-social Role of Museums", July 19, 2016. Musing on Culture, http://musingonculture-en.blogspot.com/2016/07/guest-post-social-role of- museumsnew.html (visited on $13^{\text {th }}$ Decembre 2019).

HAMMERSLEY, Martyn. 2003. "Can and Should Educational Research be Educative?". Oxford Review of Education 29(1): 3-25. https://doi.org/10.1080/03054980307433

HEIN, George E. 2010. "The Role Of Museums In Society: Education And Social Action". Curator 48(4): 357-363. https://doi.org/10.1111/j.2151-6952.2005.tb00180.x

ICOM, Development of the Museum Definition according to ICOM Statutes (2007 - 1946), http://archives.icom.museum/hist_def_eng.html (visited on $2^{\text {nd }}$ Octobre 2019).

JELAVIĆ, Željka. 2011. "O statusu i profesionalizaciji muzejske edukacije u Hrvatskoj”. In: Zbornik radova 1. kongresa muzealaca Hrvatske, Žarka Vujić, ed. Zagreb: Hrvatsko muzejsko društvo p. 58-62. http://muzejska-edukacija.com/o-statusu-i-profesionalizacijimuzejske-edukacije-i-u-hrvatskoj/ (visited on $10^{\text {th }}$ March 2012).

LASZLO, Želimir. 1997. “Što je u muzeju oduševilo Baltazara?”. Informatica Museologica 1/4: 22-26.

LEINER, Vesna and Renata BREZINŠČAK. 2016. "Djelovanje Sekcije za muzejsku pedagogiju i kulturnu akciju HMD-a". Vijesti muzealaca i konzervatora p. 38-47.

MAJANOVIĆ, Nada. 1994. "Dr. Bauer i... muzejska pedagogija”. Muzeologija 31: 29-33.

MUZEJSKI DOKUMENTACIJSKI CENTAR, Hrvatski muzeji i zbirke online, https://hvm. mdc.hr/ (visited on $10^{\text {th }}$ June 2018).

Pravilnik o stručnim muzejskim zvanjima i drugim zvanjima u muzejskoj djelatnosti te uvjetima i načinu njihova stjecanja. (NN 104/2019) (visited on $30^{\text {th }}$ October 2019)

https://narodne-novine.nn.hr/clanci/sluzbeni/full/2019_10_104_2089.html (visited on 23 ${ }^{\text {th }}$ March 2020)

SMETKO, Andreja. 2006. "11. Muzejska edukativna i nagradna igra Zvuk... Ton...Glas". Informatica Museologica 37 (1-4): 218-219.

ŠKARIĆ, Mila. 2002. "Muzejska pedagogija u Hrvatskoj”. In: II. Skup muzejskih pedagoga Hrvatske s međunarodnim sudjelovanjem, Mila Škarić ed. Zagreb: Hrvatsko muzejsko društvo p. 7-13.

ŠKARIĆ, Mila. 2007. "Solisti ili članovi orkestra”. In: IV. Skup muzejskih pedagoga Hrvatske s međunarodnim sudjelovanjem, Božidar Pejković, ed. Zagreb: Hrvatsko muzejsko društvo p. 27-36.

ŠKARIĆ, Mila. 2010. “Kriza i analiza statusa muzejskih pedagoga hrvatske 2010.”. In: VI. skup muzejskih pedagoga Hrvatske s međunarodnim sudjelovanjem. Željka Jelavić and Renata Brezinščak, ed. Zagreb: Hrvatsko muzejsko društvo, p. 19-35.

WINTZERITH, Stéphanie (ed.) 2018a. ICOM Education 28 - Cultural Action. Paris: ICOM CECA.

WINTZERITH, Stéphanie 2018b. "As way of introduction”. In: ICOM Education 28 - Cultural Action, Stéphanie Wintzerith ed. Paris: ICOM CECA, Paris: ICOM CECA p. 7-21.

Zakon o muzejima, (NN 61/2018), (NN 98/2019.). https://www.zakon.hr/z/302/Zakon-omuzejima (visited on $17^{\text {th }}$ April 2020). 